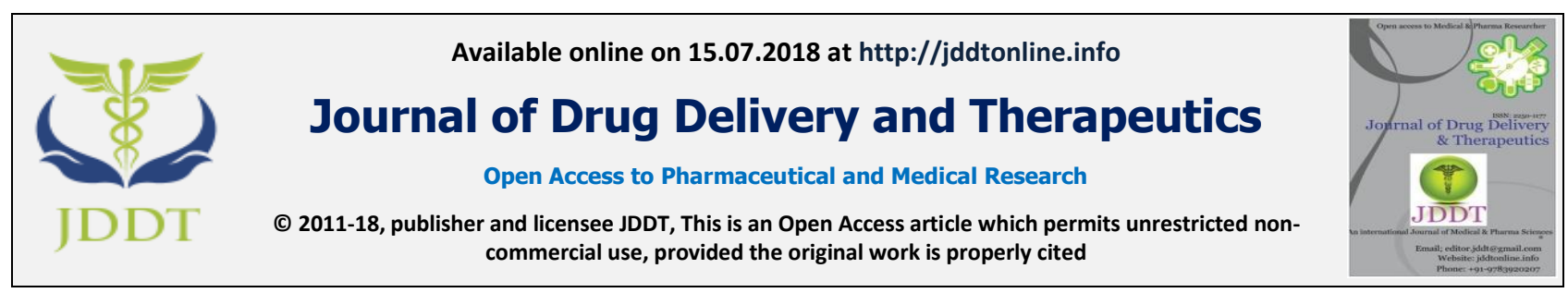

Open $\odot$ Access

Research Article

\title{
EVALUATION OF CYTOPROTECTIVE EFFICACY OF ARISAEMA LESCHNAULTII BLUME AGAINST CYCLOPHOSPHAMIDE INDUCED HEPATOTOXICITY IN TUMOR BEARING MICE
}

\author{
Yogendra Mavai*, Suman Jain \\ Department of Pharmacology, Jiwaji University, Gwalior, M.P., India
}

\section{ABSTRACT}

Cyclophosphamide (CP) is a widely used antineoplastic drug, it is used for the treatment of several malignancies. However, upon treatment, it induces severe toxicity due to its oxidative stress capability In this study we evaluate the cytoprtective efficacy of Arisaema leschnaultii blume (AL) against cyclophosphamide induced hepatotoxicity in tumor bearing mice due to its antioxidant property. Female Swiss albino mice were used. Group I-Naive control, Group II-DAL bearing, Group III-DAL + CP, Group IV$\mathrm{DAL}+\mathrm{AL}+\mathrm{CP}$, Group V- DAL + AL + CP, Group VI-DAL + Amifostine + CP. CP induced hepatic damage as indicated by significant elevation $(\mathrm{P}<0.05)$ in aspartate aminotransferase, organ weight, and evidence by the histological study. $\mathrm{CP}$ also induced hepatic oxidative stress as indicated by significant elevation $(\mathrm{P}<0.05)$ in malondialdehyde content, hydrogen peroxide $(\mathrm{H} 2 \mathrm{O} 2)$ generation, nitrite level, and the level of glutathione (GSH) peroxidase crashed in the CP treated group. AL enhanced the antioxidant defense system as indicated by elevation in GSH level, catalase activity, and GSH-S-transferase activity and by inhibiting MDA.

Keywords: hepatotoxicity, glutathione, antioxidants, cytoprotective etc.

Article Info: Received 03 March, 2018; Review Completed 24 May 2018; Accepted 29 May 2018; Available online 15 July 2018

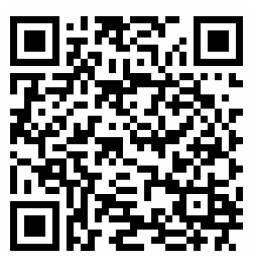

Cite this article as:

Mavai Y, Jain S, Evaluation of cytoprotective efficacy of Arisaema leschnaultii blume against cyclophosphamide induced hepatotoxicity in tumor bearing mice, Journal of Drug Delivery and Therapeutics. 2018; 8(4):134-141 DOI: $\underline{\text { http://dx.doi.org/10.22270/jddt.v8i4.1738 }}$

*Address for Correspondence:

Yogendra mavai, SOS in pharmaceutical sciences, Jiwaji University, Gwalior (M.P), India

\section{INTRODUCTION}

Cyclophosphamide (CP) is a cytotoxic alkylating agent that has been in clinical use for over 50 years and it is effective in the treatment of neoplastic diseases such as solid tumors and lymphomas as well as nonneoplastic diseases such as rheumatoid arthritis and systemic lupus erythematosus. ${ }^{1}$ However, the clinical use of CPA has been limited due to its ability to damage normal tissues which usually resulted in multiple organ toxicity mainly in the heart, testes, and urinary bladder. ${ }^{2}$ Hepatotoxicity is a major side effect of CPA as it is metabolized principally within the hepatocytes by hepatic microsomal cytochrome p450 mixed function oxidase system to produce its two active metabolite phosphoramide mustard and acrolein., Phosphoramide is associated with its immunosuppressive and antineoplastic effect, while acrolein is associated with its toxic effect. ${ }^{\mathbf{5 , 6}}$ Studies have suggested that oxidative stress is associated with its hepatotoxic effect. ${ }^{7}$ CPA toxicity results from acrolein binding to cellular antioxidant nucleophiles such as glutathione (GSH) resulting in the depletion of the antioxidant defense system and it also initiates lipid peroxidation(LPO). ${ }^{\mathbf{8}}$

Cytoprotective agents offer opportunities to reduce the treatment-related toxicity of anticancer therapy and perhaps to increase the dose and dose intensity of radiation and chemotherapy. ${ }^{9}$ Over 4000 cytoprotective agents were studied i.e.drde-07, herbal extract, Vit C, Vit E etc. ${ }^{10}$ The plant, Arisaema leschenaultii (Family Araceae) is a small tree distributed in the greater part of India on the hills of Assam, Karnataka, Kerala and 
Tamilnadu has the antioxidant activity. ${ }^{\mathbf{1 1}}$ In this study we examine the cytoprtective efficacy of Arisaema leschnaultii blume against cyclophosphamide induced hepatotoxicity in tumor bearing mice.

\section{MATERIALS AND METHODS}

\section{MATERIALS}

\section{Chemicals}

Cyclophosphamide, amifostine, DTNB, alanine aminotransferas, alkaline phosphate, aspartase,bovine serum albumin,Bradford reagent, disodium hydrogen phosphate, disodium EDTA, EDTA, ethyl alcohol, formaldehyde, glacial meta phosphoric acid. Glutathione, lactate dehydrogenase, potassium chloride, ripa buffer, sodium chloride,tris buffer, sodium dihydrogen phosphate, thiobarbituric acid, tris carboxylic acid.

\section{Animals}

Female Swiss albino mice (25-30 g) were obtained from the central animal facility of Jiwaji University Gwalior and were maintained in polypropylene cages on rodent pellet condition of controlled temperature $\left(22 \pm 2{ }^{\circ} \mathrm{C}\right)$ and acclimatized to $12 / 12 \mathrm{~h} \mathrm{light/dark}$ cycle. Free access to food and water were allowed until $2 \mathrm{~h}$ before the experiment. The care and maintenance of the animals were as per the approved guidelines of the "Committee for the purpose of control and supervision of experiments on animals (CPCSEA)". Food and water were provided $2 \mathrm{~h}$ after the experiment. All experiments on animals were conducted according to the guidelines of establishment's ethical committee on animal experimentation.

\section{Plant Extraction}

Ethanol extraction For preparation of ethanol extract $10 \mathrm{~g}$ of root powder was dissolved in $100 \mathrm{ml}$ of ethanol and kept at 270C for two days and filtered through Whatmann no. 1 filter paper. The filtrate was then allowed to evaporate to get concentrated filtrate which was again reconstituted in small volumes of same solvent. The solvent was air-dried and the extract was weighed.

\section{METHODS}

\section{Induction of Tumor}

$5 \times 10^{6}$ cells of Dalton's lymphoma (DAL) were injected in the peritoneal cavity of each animal on day 0 . Cyclophospamide (CP) $(200 \mathrm{mg} / \mathrm{kg})$ was administered intraperitoneally (i.p) to groups of mice on day 3 after inoculation of Dalton's Lymphoma (DAL) for 7 consecutive days. AL $(100 \mathrm{mg} / \mathrm{kg}, 200 \mathrm{mg} / \mathrm{kg})$ and Amifostine $(300 \mathrm{mg} / \mathrm{kg}$ ) was given orally $30 \mathrm{~min}$ prior to $\mathrm{CP}$ administration for 12 days. . Group I-Naive control, Group II-DAL bearing, Group III-DAL + CP, Group IV- DAL + AL + CP, Group V- DAL + AL + $\mathrm{CP}$, Group VI-DAL + Amifostine $+\mathrm{CP}$. The body weights of the animals were recorded daily up to 12 days and after 12 days animals were anaesthetized with ether for collection of blood from orbital sinus, and then sacrificed by cervical dislocation for the removal of vital organ. Various haematological and biochemical analysis were carried out.

\section{Biochemical estimation}

Blood biochemistry, hepatic glutathione and hepatic MDA were estimated after the exposure. Hepatic Glutathione concentration of tissue was assayed according to method. Blood GSH was estimated by the method ${ }^{12}$ Beutler et al. (1963). In brief, 150 milligram of tissue was homogenized in 0.02 M EDTA buffer ( $\mathrm{pH}$ 8.0 ) and $50 \%$ TCA was added to it. Supernatant was mixed with $0.4 \mathrm{M}$ tris buffer $(\mathrm{pH} 8.9)$, and $0.01 \mathrm{M}$ DTNB (5, 5'- Dithio- bis- (2-nitrobenzoic acid) and absorbance was read at $410 \mathrm{~nm}{ }^{\mathbf{1 3}}$. Hepatic lipid peroxidation was determined by measuring the level of thiobarbituric acid substance (TBARS) formed, using thiobarbituric acid (TBA), according to the method ${ }^{\mathbf{1 4}}$. Blood $\mathrm{Hb}, \mathrm{RBC}$ and $\mathrm{WBC}$ were analyzed by using Bechman Coulter Analyzer (USA). SGPT, SGOT, ALP and total protein concentrations were estimated by using kits (Ecoline, Merck).

\section{Thiol assay}

The reaction mixture containing $900 \mu \mathrm{L} 2 \mathrm{mM} \mathrm{Na}_{2}$ EDTA in $0.2 \mathrm{M} \mathrm{Na}_{2} \mathrm{HPO}_{4}, 20 \mu \mathrm{L} 10 \mathrm{mM}$ DTNB in $0.2 \mathrm{M} \mathrm{Na}_{2} \mathrm{HPO}_{4}$ and $100 \mu \mathrm{L}$ serum was incubated at room temperature for $5 \mathrm{~min}$; the absorbance was read at $412 \mathrm{~nm}$. Appropriate sample and reagent blanks were prepared simultaneously and the respective absorbance was noted. Corrected absorbance values were used to calculate serum protein thiol content using a molar extinction coefficient of $1600 / \mathrm{M} / \mathrm{cm}$ and values were expressed as $\mathrm{mM}$. The calibration curve was produced using GSH dissolved in phosphate-buffered saline (PBS) ${ }^{15}$

\section{GST assay}

One $\mathrm{mL}$ of reaction mixture containing $850 \mu \mathrm{L}$ of $0.1 \mathrm{M}$ phosphate buffer, $\mathrm{pH} 6.5,50 \mu \mathrm{L} 20 \mathrm{mM}$ CDNB (1-chloro 2,4-dinitrobenzene) and $50 \mu \mathrm{L} 20 \mathrm{mM} \mathrm{GSH}$ was pre-incubated at $37^{\circ} \mathrm{C}$ for $10 \mathrm{~min}$. Reaction was started by adding $50 \mu \mathrm{L}$ serum and GST activity was assayed kinetically. Reaction was followed at one minute intervals for five minutes by measuring the absorbance at 340nm. GST was determined by using a molar extinction coefficient of $9.6 / \mathrm{mM} / \mathrm{cm}$ and GST activity was expressed as IU/L. ${ }^{16}$ and (Harvey, J.W. et al., 1982)

\section{MDA assay}

The reaction mixture containing $1 \mathrm{~mL} \quad 0.67 \%$ thiobarbituric acid (TBA), $1 \mathrm{~mL} 20 \%$ tricarboxylic acid (TCA), and $100 \mu \mathrm{L}$ serum was incubated at $100{ }^{\circ} \mathrm{C}$ for $20 \mathrm{~min}$ and centrifuged at $12,000 \mathrm{rpm}$ for $5 \mathrm{~min}$. The absorbance of the supernatant was read at $532 \mathrm{~nm}$ and MDA concentration was determined by using a molar extinction coefficient of $1.56 \times 10^{5} / \mathrm{M} / \mathrm{cm}$ and the values were expressed as $\mathrm{mM} .{ }^{17}$

\section{Determination of SOD aaand cataase}

The determination of hepatic superoxide dismutase (SOD) activity by measuring the inhibition of 
autooxidation of epinephrine at $\mathrm{pH} 10.2$ and $30{ }^{\circ} \mathrm{C}$. SOD activity was expressed in $\mathrm{U} / \mathrm{mg}$ protein. Hepatic catalase activity was determined according to the method of ${ }^{\mathbf{1 8}}$. by measuring the reduction of dichromate in acetic acid to chromic acetate at $570 \mathrm{~nm}$. Catalase activity was expressed as $\mu \mathrm{mol} \quad \mathrm{H}_{2} \mathrm{O}_{2}$ consumed/min/mg protein.

\section{Protein Expression (Western Blotting)}

$20 \%$ tissue was homogenated in RIPA lysis buffer (Sigma, U.S.A.). Equal amounts of proteins (quantified by Bradford assay) were mixed with Laemmli sample buffer, resolved on 12\% SDS-poly-acrylamide gel and transferred to polyvinylidene difluoride membranes (Millipore). The membranes were blocked with a buffer containing 5\% non-fat skimed milk powder in PBST $(1 \times$ PBS, $0.2 \%$ Tween 20$)$ at $4^{\circ} \mathrm{C}$ for 1 hour, and subsequently incubated in the same buffer containing primary caspase-3 antibodies in 1:2000 dilution (Santa Cruz Biotechnology, Santa Cruz, CA) for overnight at $4^{\circ} \mathrm{C}$ and then membrane was washed by PBS-T and incubated for secondary antibodies for 1 hour. The Proteins bands were identified by using an enhanced chemiluminescence detection system in accordance with the manufacturer's instructions (ECL or ECL, Amersham Biosciences).

\section{- Histopathological Studies}

Liver tissues of mice were removed and washed with normal saline. The cleared tissue was fixed in $10 \%$ natural buffered formalin solution $(\mathrm{pH}$ 7.0-7.2). After proper fixation tissue was processed for dehydration in ascending grade of ethanol, clearing with toluene, followed by impregnation in paraffin wax, then sections of $5 \mu$ in thickness were cut with help of semiautomatic rotary microtome. Sections were stained with hematoxyline. Stained paraffin sections of liver were examined under phase contrast microscope (Lieca DMLB) and photomicrographs were taken. Representive area were captured and analyzed with the help of Lieca Qwin V3 digital image processing and analysis system.

\section{- Hepatic Apoptosis Determination (TUNEL Assay)}

Apoptosis was measured by the identification of apoptotic nuclei in sections of liver by fragment end labeling of DNA (Apoptosis detection kit, Chemicon, USA). In, brief, endogenous peroxidase activity was inactivated by $3 \%$ hydrogen peroxides. The DNA fragments were allowed to bind an antidigoxigenin antibody that was conjugated to a peroxidase. Diaminobenzidine (DAB) was applied to develop dark brown colour and then the slides were counterstained with haematoxylin. All fields in each sample were evaluated for positive stained liver cell. The results were expressed as the number of positive stained cells per high-power field.

\section{- Organ to Body Weight Indices (OBWI)}

After sacrificing the animals, Liver was removed and the washed free of extraneous materials and weighed.
The organ to body weight indices (OBWI) were calculated as per the formula given below:

$$
O B W I=\frac{\text { Organ Weight }}{\text { Body Weight }} \times 100
$$

\section{- Statistical Analysis}

Statistical evaluations were made using one-way ANOVA followed by Dunnet's test. A probability of 0.05 and less was taken as statistically significant. The analyses were carried out using sigma stat for windows version 2.03 (SPSS Inc.USA).

\section{RESULTS}

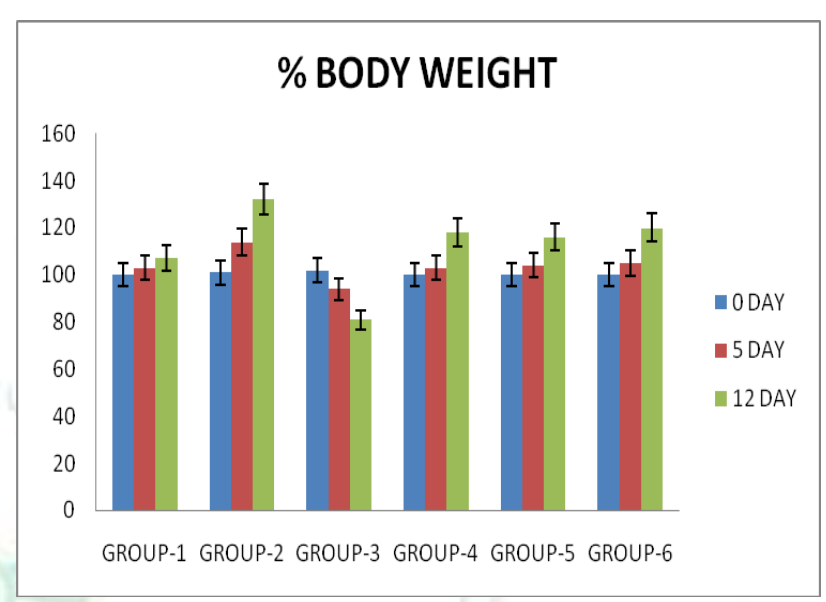

$\mathrm{P}<0.05$, as compared to control group (One Way ANOVA followed by Dunnett's t test).

Figure 1: Effect of pretreatment of AL $(100 \mathrm{mg} / \mathrm{kg}), \mathrm{AL}$ $(200 \mathrm{mg} / \mathrm{kg})$ and Amifostine on body weight of CP treated tumor bearing mice.

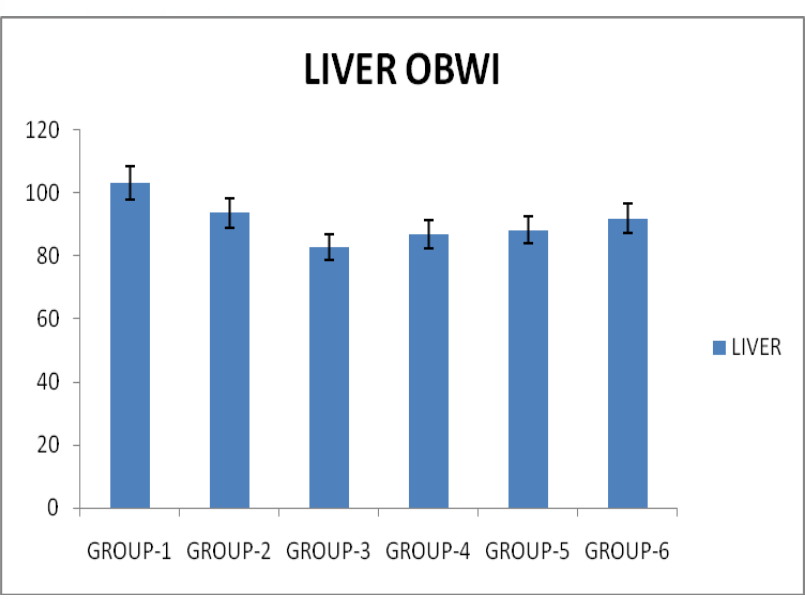

$* \mathrm{P}<0.05$, as compared to control group (One Way ANOVA followed by Dunnett's t test).

Control values for liver OBWI $=8 \pm 0.06$

Figure 2: Effect of pretreatment of AL (100mg/kg), AL $(200 \mathrm{mg} / \mathrm{kg})$ and Amifostine on liver organ body weight indices (OBWI). 


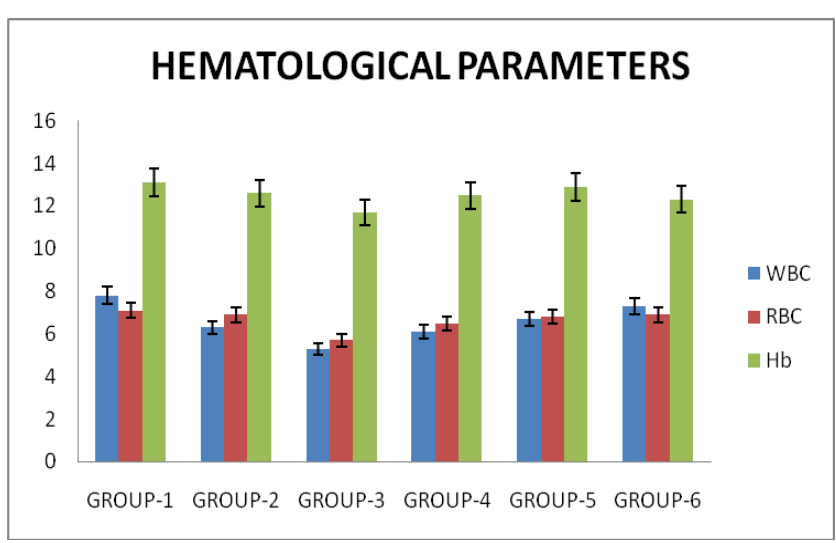

$* \mathrm{P}<0.05$, as compared to control group (One Way ANOVA followed by Dunnett's t test).

Control values for $\mathrm{WBC}=7.4 \pm 0.7 \times 10^{3} \mathrm{cell} / \mu \mathrm{l} ; \mathrm{RBC}=8.4 \times$ $10^{6}$ cells $/ \mu \mathrm{l} ; \mathrm{Hb}=13.2 \pm 0.4 \mathrm{~g} / \mathrm{dl}$

Figure 3: Effect of pretreatment of AL $(100 \mathrm{mg} / \mathrm{kg}), \mathrm{AL}$ (200mg/kg) and Amifostine on \% WBC, RBC and $\mathrm{Hb}$ levels in $\mathrm{CP}$ treated tumor bearing mice.

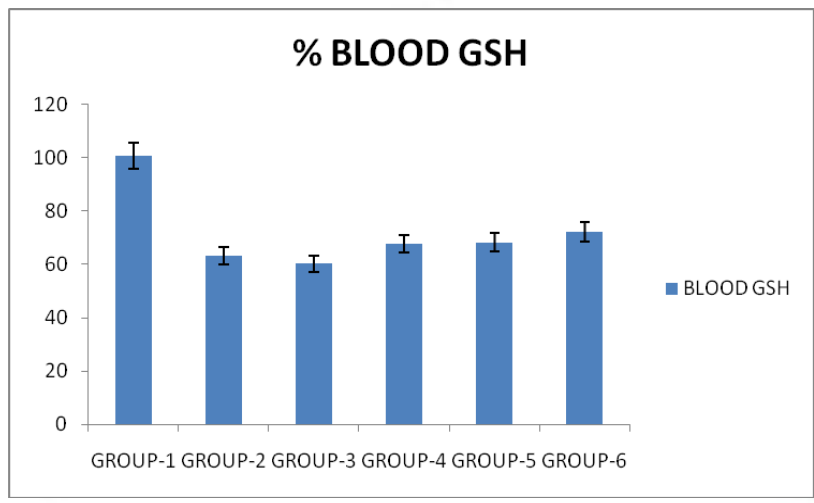

$* \mathrm{P}<0.05$, as compared to control group (One Way ANOVA followed by Dunnett's t test)

Control values for Blood GSH=0.075 $\pm 0.05 \mathrm{mg} / \mathrm{dl}$.

Figure 4: Effect of pretreatment of AL (100mg/kg), AL $(200 \mathrm{mg} / \mathrm{kg})$ and Amifostine on blood GSH ( $\mu$ moles/mg) levels in SM treated tumor bearing mice.

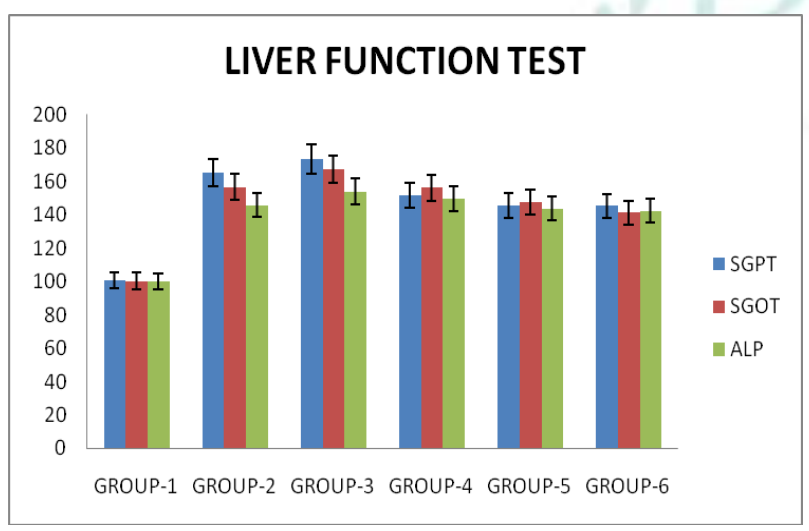

$* \mathrm{P}<0.05$, as compared to control group (One Way ANOVA followed by Dunnett's t test).

Control values for SGPT $=25 \pm 1.01 \mathrm{IU} / \mathrm{L} ; \mathrm{SGOT}=$ 26.1 $\pm 1.02 \mathrm{IU} / \mathrm{L} ; \mathrm{ALP}=29.2 \pm 2.1 \mathrm{IU} / \mathrm{L}$

Figure 5: Effect of pretreatment of AL $(100 \mathrm{mg} / \mathrm{kg}), \mathrm{AL}$ $(200 \mathrm{mg} / \mathrm{kg})$ and Amifostine on SGPT (IU/L), SGOT (IU/L) and ALP (IU/L) levels in CP treated tumor bearing mice.

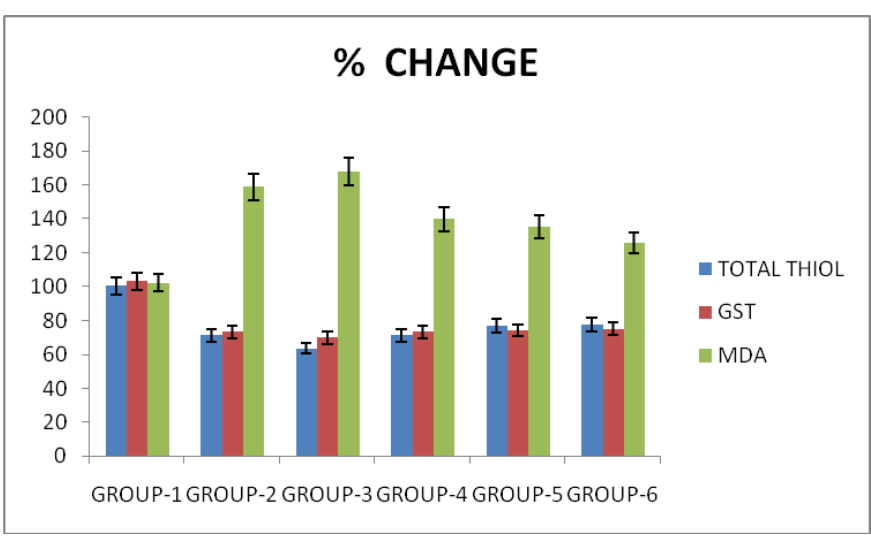

$* \mathrm{P}<0.05$, as compared to control group (One Way ANOVA followed by Dunnett's t test)

Control values for GST $=0.248 \pm 0.05 \mathrm{IU} / \mathrm{L}$; Total thiol $=$ $0.193 \pm 0.07 \mathrm{mM} ; \mathrm{MDA}=0.22 \pm 0.08 \times 10^{-3} \mathrm{mM}$

Figure 6: Effect of pretreatment of AL (100mg/kg), AL (200mg/kg) and Amifostine on \% plasma GST (IU/L), total thiol (mM) and MDA (mM) levels in CP treated tumor bearing mice.

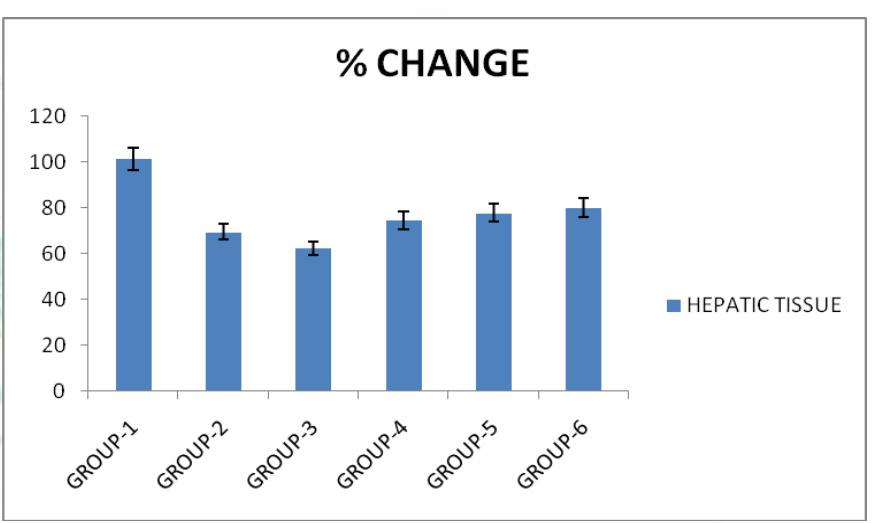

$* \mathrm{P}<0.05$, as compared to control group (One Way ANOVA followed by Dunnett's t test).

Control values for $\mathrm{GSH}=7.2 \pm 0.4 \mu$ moles/gm of tissue

Figure 7: Effect of pretreatment of AL $(100 \mathrm{mg} / \mathrm{kg})$, AL $(200 \mathrm{mg} / \mathrm{kg})$ and Amifostine on hepatic \% GSH ( $\mu$ moles $/ \mathrm{mg}$ ) levels in CP treated tumor bearing mice.

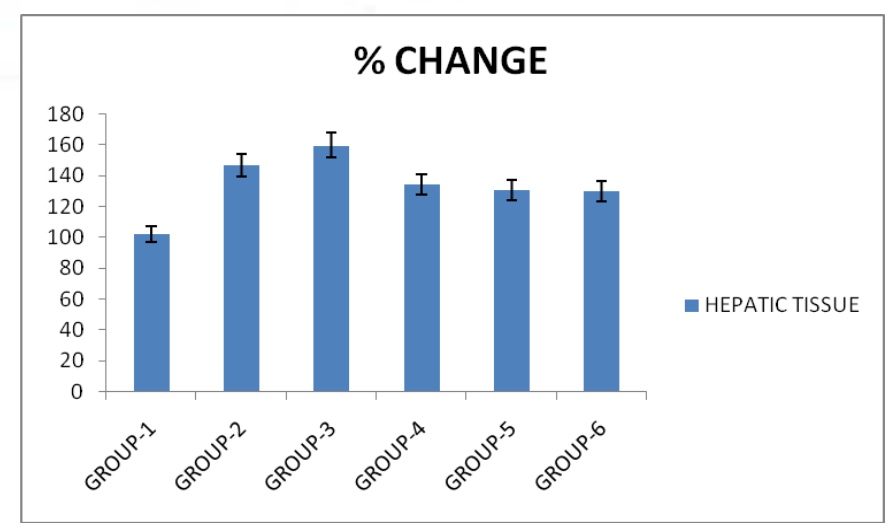

$* \mathrm{P}<0.05$, as compared to control group (One Way ANOVA followed by Dunnett's $t$ test).

Control value for MDA $=4.43 \pm 0.5 \mathrm{nmol} / \mathrm{gm}$ of tissue.

Figure 8: Effect of pretreatment of AL (100mg/kg), AL $(200 \mathrm{mg} / \mathrm{kg})$ and Amifostine on hepatic \% MDA (nmol/mg protien) levels in SM treated tumor bearing mice. 


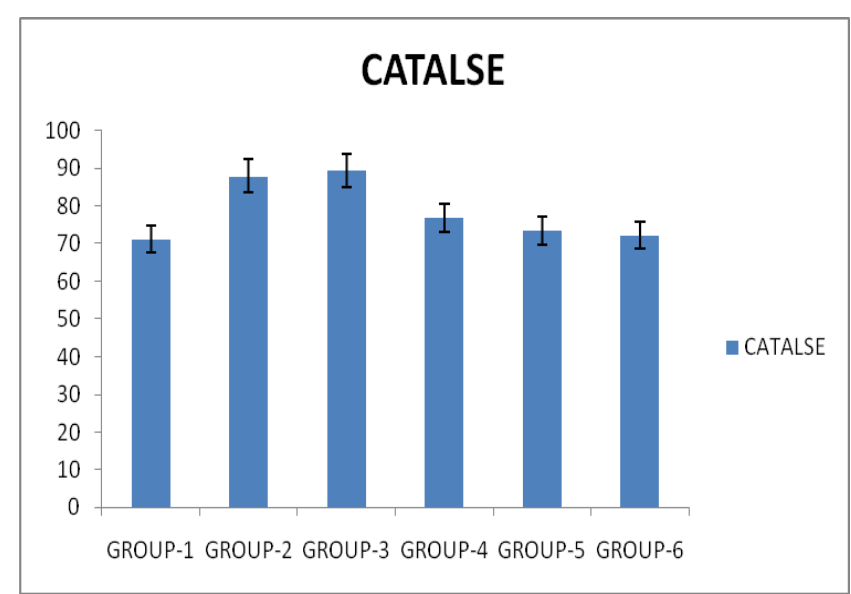

*P $<0.05$, as compared to control group (One Way ANOVA followed by Dunnett's t test).

Control value for CATALASE $=72.12 \pm 0.7 \mathrm{U} / \mathrm{mg}$ protein .

Figure 9: Effect of pretreatment of AL AL (100mg/kg), AL $(200 \mathrm{mg} / \mathrm{kg}$ ) and Amifostine on catalase (U/mg protein) levels in CP treated tumor bearing mice.

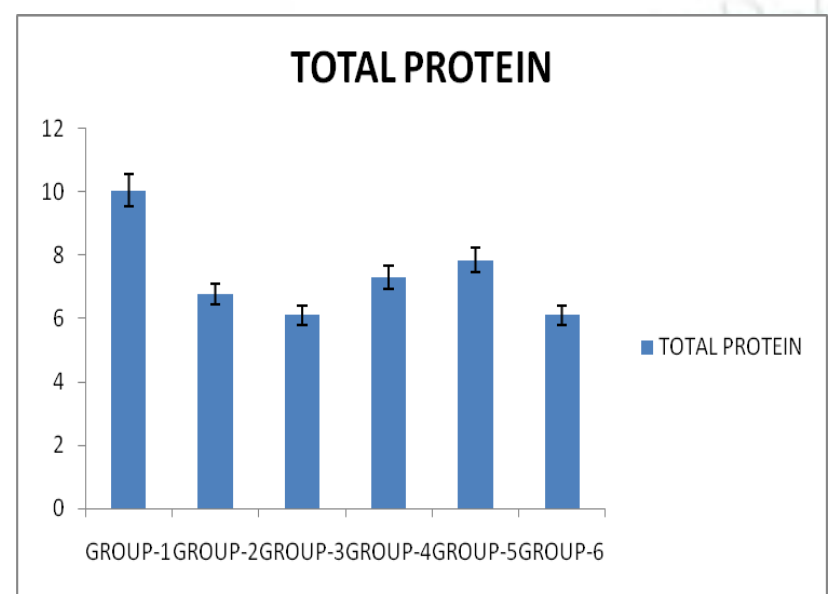

$* \mathrm{P}<0.05$, as compared to control group (One Way ANOVA followed by Dunnett's t test).

Control value for TOTAL PROTEIN $=10.02 \pm 0.37$ $\mathrm{U} / \mathrm{mg}$ protein.

Figure 10: Effect of pretreatment of AL AL $(100 \mathrm{mg} / \mathrm{kg}), \mathrm{AL}(200 \mathrm{mg} / \mathrm{kg})$ and Amifostine on total protein $(\mathrm{U} / \mathrm{mg}$ protein) levels in $\mathrm{CP}$ treated tumor bearing mice.

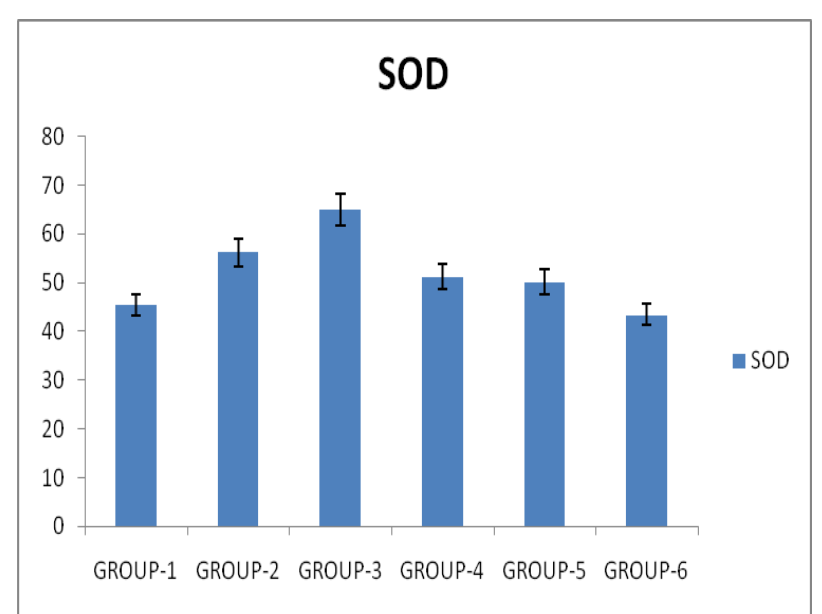

$* \mathrm{P}<0.05$, as compared to control group (One Way ANOVA followed by Dunnett's t test).

Control value for $\mathrm{SOD}=45.41 \pm 0.67 \mathrm{U} / \mathrm{mg}$ protein.

Figure 11: Effect of pretreatment of AL AL $(100 \mathrm{mg} / \mathrm{kg}), \mathrm{AL}(200 \mathrm{mg} / \mathrm{kg})$ and Amifostine on SOD (U/mg protein) levels in CP treated tumor bearing mice.

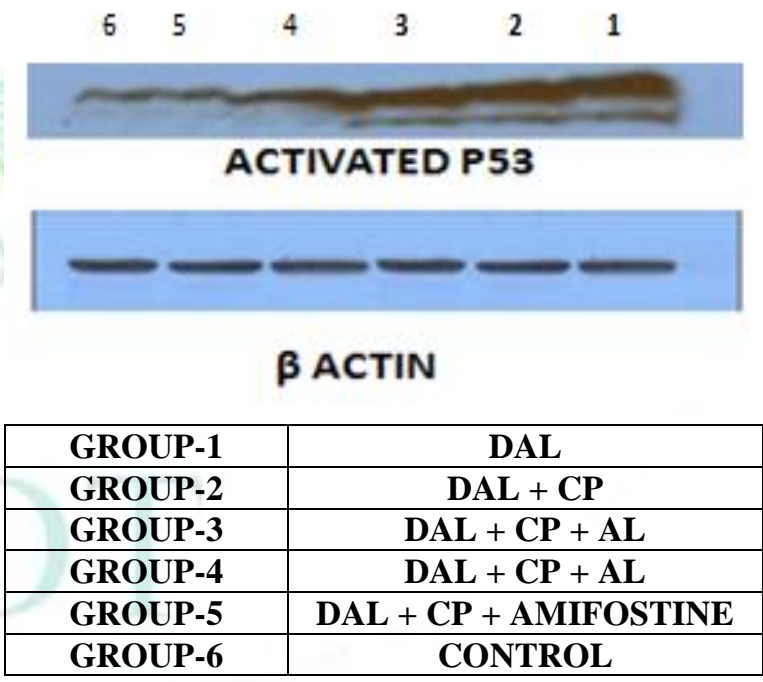

Figure 12: Effect of pretreatment of AL $(100 \mathrm{mg} / \mathrm{kg})$,

AL $(200 \mathrm{mg} / \mathrm{kg})$ and Amifostine on Caspase-3 protein expression in $\mathrm{CP}$ treated tumor bearing mice. 


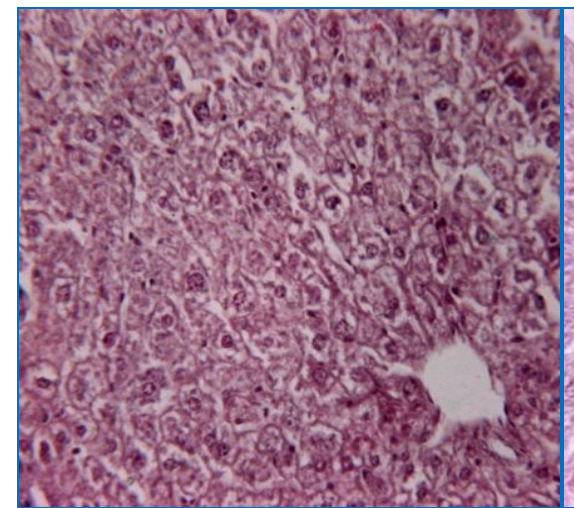

(A) Control

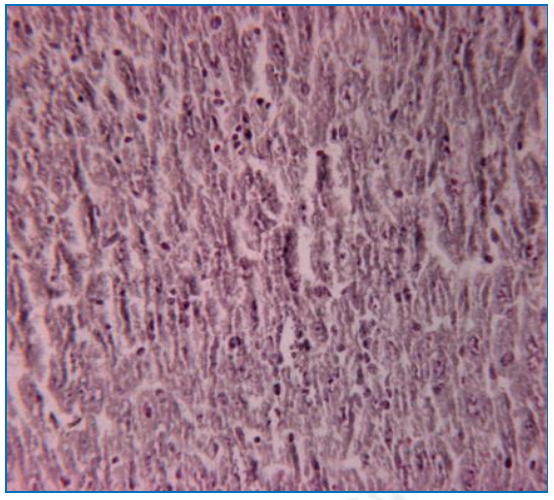

(D) $\mathrm{DAL}+\mathrm{AL}+\mathrm{CP}$

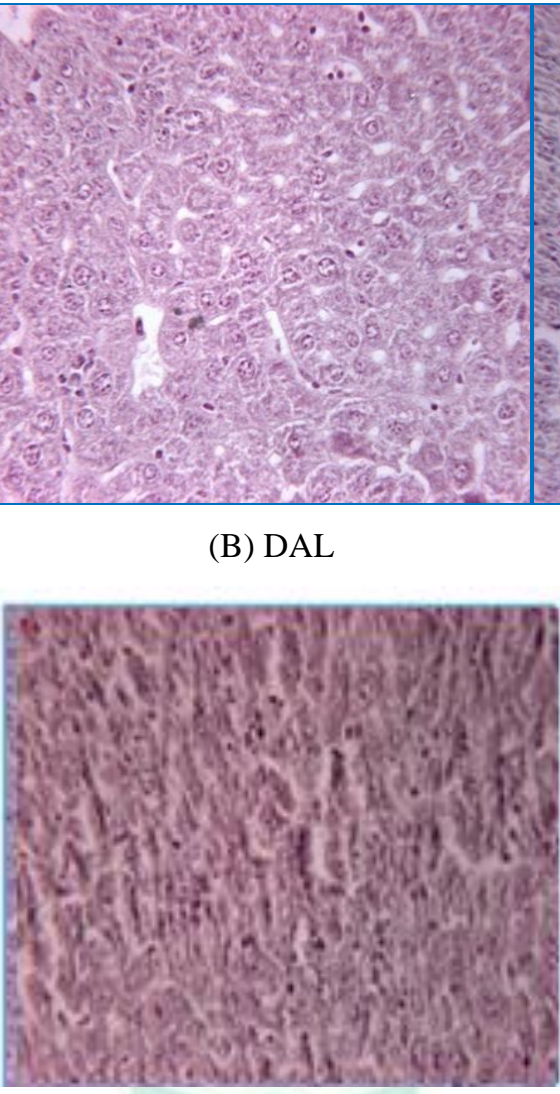

(E) $\mathrm{DAL}+\mathrm{AL}+\mathrm{CP}$
(F) $\mathrm{DAL}+\mathrm{Ami}+\mathrm{CP}$

Figure 13 (A-F): Photomicrographs of CP administered (200 mg/kg, pc), AL (100mg/kg), AL (200mg/kg) on mice liver and other treatment

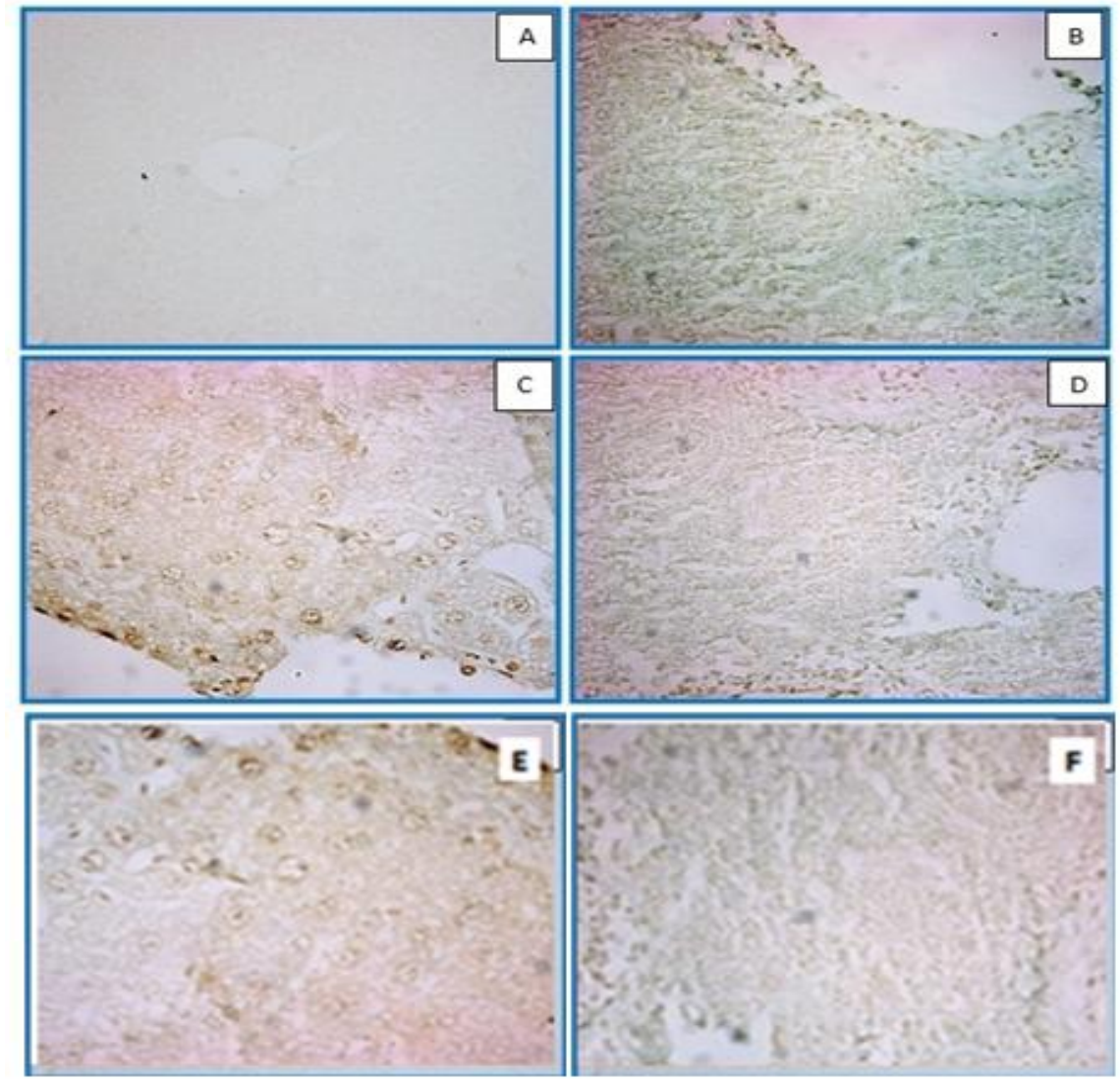

Figure 14 (A-F): Effect of pretreatment of AL (100mg/kg), AL (200mg/kg) and Amifostine on hepatocytes in CP treated tumor bearing mice (A) Control; (B) DAL (C) DAL+AL+CP; (D) DAL+AL+CP; (E) DAL+AL+CP ; (F) $\mathrm{DAL}+$ Amifostine+CP 
As per the literature the estimated cytotoxic dose of cyclophospamide is $200 \mathrm{mg} / \mathrm{kg}$. All the DAL bearing mice treated with $200 \mathrm{mg} / \mathrm{kg}$ of $\mathrm{CP}$ to induce hepatotoxicity.

In fig1 the percentage increase in body weight was significant $(\mathrm{p}<0.05)$ in treated groups compared to naive group. Body weight was increased significantly in DAL bearing mice $(p<0.05)$ compared to naive group where as in CP treated mice body weight was significantly decreased compare to naïve control group. Body weight was not significantly changed by pretreatment of $\mathrm{AL}$ $(100 \mathrm{mg} / \mathrm{kg}, 200 \mathrm{mg} / \mathrm{kg})$ and Amifostine in CP treated tumor bearing mice compared to naïve control mice. No significant change was found in liver weight in any groups compared to control group (Figure2).

Figure 3 shows, WBC, RBC count and Hemoglobin level after $200 \mathrm{mg} / \mathrm{kg}$ of $\mathrm{CP}$ and other treatments in tumor bearing mice. There was significant $(p<0.05)$ fall in the WBC, RBC and $\mathrm{Hb}$ count in DAL mice and $\mathrm{CP}$ treated mice compared to healthy control mice. A moderate improvement in $\mathrm{WBC}, \mathrm{RBC}$ and $\mathrm{Hb}$ count was observed in $\mathrm{AL}(100 \mathrm{mg} / \mathrm{kg}, 200 \mathrm{mg} / \mathrm{kg})$ and Amifostine treated mice but changes were not significant as compared to control group.

Figure 4 summaries, the changes in the reduced glutathione levels in blood. There was significant decrease $(p<0.05)$ in blood glutathione level in tumor bearing mice and $\mathrm{CP}$ treated mice compared to naive group. In AL $100 \mathrm{mg} / \mathrm{kg}, 200 \mathrm{mg} / \mathrm{kg}$ and Amifostine pretreated groups, blood GSH level was also significantly increased $(\mathrm{p}<0.05)$ with respect to naive group. Blood GSH level was not significantly increased by pretreatment of $\mathrm{CP}$ treated tumor bearing mice compared to DAL bearing mice.

Figure 5 shows, the activities of serum SGPT, SGOT and ALP enzymes in all treatment groups. There was a significant increase $(p<0.05)$ was observed in tumor bearing mice and $\mathrm{CP}$ treated tumor bearing mice compared to naive group. Amifostine and AL did show significant change in SGPT, SGOT and ALP activities compared to $\mathrm{CP}$ treated tumor bearing mice.

Figure 6 Summaries, the changes in the serum total thiol, lipid peroxidation and GST levels of animals of all groups. There was significant decrease in GST and total thiol level in CP treated tumor bearing mice and DAL bearing mice $(\mathrm{P}<0.05)$ compared to healthy control group. AL $(100 \mathrm{mg} / \mathrm{kg}, 200 \mathrm{mg} / \mathrm{kg})$ and Amifostine treatment with $\mathrm{CP}$ in tumor bearing mice showed significant increase in serum GST and total thiol level compared to DAL bearing mice. Serum MDA level was significantly increased in DAL tumor bearing mice and $\mathrm{CP}$ treated mice with respect to healthy control group $(p<0.05)$ and significant change has been observed by AL $(100 \mathrm{mg} / \mathrm{kg}, 200 \mathrm{mg} / \mathrm{kg})$ and Amifostine in CP treated tumor bearing mice compared to DAL bearing mice.

Figure 7 summaries, the effect of various treatments on liver reduced glutathione levels in mice. There was significant decrease in reduced glutathione level in tumor bearing mice and $\mathrm{CP}$ treated tumor bearing mice $(\mathrm{p}<0.05)$ compared to naive group. AL $(100 \mathrm{mg} / \mathrm{kg}, 200$ $\mathrm{mg} / \mathrm{kg}$ ) and Amifostine showed any significant increase in hepatic tissue GSH level compared to DAL bearing mice.

In Figure 8 the effect of various treatments on hepatic reduced MDA levels in mice. lipid peroxidation increased significantly in DAL bearing mice and $\mathrm{CP}$ treated tumor bearing mice compared to naïve group $(\mathrm{p}<0.05)$. MDA level was decreased significantly AL $(100 \mathrm{mg} / \mathrm{kg}, 200 \mathrm{mg} / \mathrm{kg}$ ) and Amifostine pretreated tumor bearing groups compared to DAL bearing control mice.

Figure 9 shows the effect of pretreatment of $\mathrm{AL}$ and Amifostine on catalase levels in CP treated tumor bearing mice. The level of catalse significantly $(p<0.05)$ increased in DAL bearing mice and $\mathrm{CP}$ treated group compared to naïve group. The level of catalse was decreased in AL and amifostine preteated tumor bearing mice compared to DAL bearing control mice.

Figure 10 shows effect of pretreatment of $\mathrm{AL}$ and Amifostine on total protein levels in $\mathrm{CP}$ treated tumor bearing mice. The level of total protein significantly $(\mathrm{p}<0.05)$ decreased in DAL bearing mice and CP treated group compared to naïve group. The level of total protein was decreased in $\mathrm{AL}$ and amifostine preteated tumor bearing mice compared to DAL bearing control mice.

Figure 11 shows the effect of pretreatment of $\mathrm{AL}$ Amifostine on SOD levels in CP treated tumor bearing mice. The level of SOD significantly $(p<0.05)$ decreased in DAL bearing mice and CP treated group compared to naive group. The level of SOD was decreased in AL and amifostine preteated tumor bearing mice compared to DAL bearing control mice.

Figure 12 shows, the expression of $\mathrm{P}^{53}$ protein in liver of animals of various treatment groups. The western blot indicated that tumor results in the activation of $\mathrm{P}^{53}$ protein in liver tissue. CP treated groups shows significantly reduction in caspase-3 protein band intensity compared to tumor bearing mice. In $\mathrm{AL}$ pretreated group $\mathrm{P}^{53}$ protein also activates as compared to naive group. AL $(100 \mathrm{mg} / \mathrm{kg}, 200 \mathrm{mg} / \mathrm{kg})$ and Amifostine treatment group does not show a significant reduction in band intensity (c $\mathrm{P}^{53}$ expressions) compared to tumor bearing mice.

In Histological evaluation, liver section of control mice showed normal cord pattern, hepatic lobule, central canal and hepatocytes (Figure13-A). DAL bearing mice liver section showed mild vacuolar degeneration of hepatocytes and condensation of chromatin material indicative of cell death (Figure 13-B). In CP treated groups liver section showed abnormal cord and rearranged architecture of hepatocytes. Pretreatment with AL also showed the dead hepatocyte and feathery degeneration (Figure 13 D, E). The liver of CP administered mice pretreated Amifostine showed minimal to moderate lesions and some hepatocytes with granular degeneration (Figure 13-F). 
Figure 14 indicates the number of apoptotic cells in liver section of animals of various groups. The number of apoptotic nuclei in the liver of control group was around 1 in a unit area (Figure 22-A). In the contrast, the numbers of apoptotic cells were observed frequently in centrilobular area in DAL group (Figure 14-B) and CP (Figure 14-C) and AL and amifostine treated tumor bearing mice (Figure 14-D,E,F) compared with control group.

\section{CONCLUSION}

Results concluded that Arisaema leschenaultia blume has accorded better protection in $\mathrm{CP}$ exposed tumor bearing mice. It not only protects the toxic effect of $\mathrm{CP}$ towards normal cells but also provides protection of tumor cells against cytotoxicity of CP. Thus Arisaema

\section{REFERENCES}

1. Lawson M, Vasilaras A, De Vries A, Mactaggart P, Nicol D. Urological implications of cyclophosphamide and ifosfamide. Scand J Urol Nephrol 2008; 42:309-17.

2. Fraiser LH, Kanekal S, Kehrer JP. Cyclophosphamide toxicity. Characterising and avoiding the problem. Drugs 1991; 42:781-95.

3. King PD, Perry MC. Hepatotoxicity of chemotherapy. Oncologist 2001; 6:162-76.

4. Ludeman SM. The chemistry of the metabolites of cyclophosphamide. Curr Pharm Des 1999; 5:627-43.

5. KernJC,KehrerJP.Acrolein-inducedcelldeath:Acaspase-infue nced decision between apoptosis and oncosis/necrosis. Chem Biol Interact 2002; 139:79-95.

6. Angulo I, Jiménez-Díaz MB, García-Bustos JF, Gargallo D, de las Heras FG, Muñoz-Fernández MA, et al. Candida albicans infection enhances immunosuppression induced by cyclophosphamide by selective priming of suppressive myeloid progenitors for NO production. Cell Immunol 2002; 218:46-58.

7. Zarei M, Shivanandappa T. Amelioration of cyclophosphamide-induced hepatotoxicity by the root extract of Decalepis hamiltonii in mice. Food Chem Toxicol 2013; 57:179-84.

8. Adams JD Jr, Klaidman LK. Acrolein-induced oxygen radical formation. Free Radic Biol Med 1993;15:187-93

9. Kouloulias, V.E.; Kouvaris, J.R. Cytoprotective Efficacy of Amifostine against Radiation- Induced Rectal Toxicity: Objective and Subjective Grading Scales for Radiomucositis. Molecules 2008, 13, 892-903.

10. Links M, Lewis C. 1999. Chemoprotectants: a review of their clinical pharmacology and therapeutic efficacy of drugs 1999;57:293-308. leschenaultii blume neutralized the cytotoxic effect of $\mathrm{CP}$ towards normal cells as well as tumor cells.

\section{FUTURE ASPECTS}

As till date, there is no specific and effective cytoprotectants available against the adverse effects of chemotherapeutic agent. Therefore, there is need for the novel agent, which protects normal tissues from the deleterious effects of chemotherapy with the absence of tumor protection and tumor growth stimulation properties.

Studies are required on Arisaema Leschnaultii Blume and various other plants and synthetic compounds to come up as promising cytoprotective agent against chemotherapeutic agents.

11. Kumar P, Vijayraghwan R, Kulkarni AS, Pathak U, Raza SK, Jaiswal DK. In vivo protection by amifostinen and DRDE-07 against sulphur mustard toxicity. Hum Exp Toxicol 2002; 21:371-76.

12. Pandey N, Barwe D, P nrajapati, Dubey BK, Antioxidant activity of Ethanolic Extract of Arisaema leschenaultii Blume Tuber., research gate

13. Beutler E, Baluda Mc. Methemoglobin reduction. Studies of the interaction between cell populations and of the role of methylene blue. Blood. 1963 Sep; 22:323-33.

14. Ohkawa H, Ohishi N, Yagi K.,Assay for lipid peroxides in animal tissues bthiobarbituric acid reaction. Anal Biochem. 1979 Jun; 95(2):351-8.

15. Sedlak J, Lindsay RHE stimation of total, protein-bound, and nonprotein sulfhydryl groups in tissue with Ellman's reagent. Anal Biochem. 1968 Oct 24; 25(1):192-205.

16. Motchink AP, Frei, Ames NB. Measurment of antioxidants in human plasma. Protein thiols, in oxygen radicals in biological systems. Methods in enzymology, part D, California, Academic press 1994; 234:273-4.

17. Habig WH, Pabst MJ,jakoby WB. Glutathione S transferases. The first enzymatic step in mercapturic acid formation. J Biol chem 1974; 249:7130-39.

18. Harvey JW, Beutler E. Binding of heme by glutathions Stransferases. A possible role of erythrocyte enzyme. Blood 1982; 60:1227-30.

19. D'souza D, Subhas BG, Shetty SR, and Balan P, Estimation of serum malondialdehyde in potentially malignant disorders and post-antioxidant treated patients: A biochemical studyContemp Clin Dent. 2012 Oct-Dec; 3(4): 448-451.

20. Christine J. Weydert and Joseph J. Cullen measurement of superoxide dismutase, catalase, and glutathione peroxidase IN cultured cells and tissue nat Protoc 2010; 5(1): 51-66. 